\title{
РОЗВИТОК ЕКСПОРТНОГО ПОТЕНЦІАЛУ МАЛИХ І СЕРЕДНІХ ПІДПРИЕМСТВ ЯК ЧИННИК КОМПЕНСАЦІЇ ВТРАТ УКРАЇНИ НА ТРАДИЦЙНИХ ЗОВНІШНІХ РИНКАХ
}

\author{
DEVELOPMENT OF EXPORT POTENTIAL OF SMALL AND MEDIUM-SIZED \\ ENTERPRISES AS A FACTOR OF COMPENSATION OF LOSSES OF UKRAINE ON \\ TRADITIONAL EXTERNAL MARKETS
}

У статті розглядається сучасний стан експортної діяльності малих $i$ середніх підприємств в Україні. Окреслено основні втрати експортного потенціалу, яких зазнала економіка України внаслідок зовнішньої агресії. Наведено основні показники, які характеризують рівень експортної діяльності малих і середніх підприємств. До чинників, щзо обмежують можливості малих і середніх підприємств брати участь у зовнішній торгівлі віднесено: ускладнені вимоги щуодо отримання регуляторних умов при здійсненні експортних операчій, відсутність високих стандартів проведення митних процедур, обмежений доступ до інформації про ситуацію на зовнішніх ринках, низька результативність існуючої системи сприяння налагодженню контактів з потенційними зарубіжними партнерами, низький кваліфікаційний рівень менеджменту малих $і$ середніх компаній в питаннях управління зовнішньоекономічною діяльністю, відсутність вичерпно регламентованих механізмів застосування процедур і регуляторних вимог при здійсненні зовнішньоторговельних операцій, низький рівень доступності експортного кредитування, недостатня результативність державних програм підтримки експорту, наявність мовних і культурних бар'єрів. На основі визначення специфіки та проявів перешкод для експортної діяльності малих $i$ середніх підприємств запропоновано низку заходів державної політики, призначених для створення умов для поступового нарощування експортного потенщіалу малих і середніх підприємств $i$ посилення позицій краӥни на зовнішніх ринках. Ці заходи мають бути спрямовані на спрощення процедур і регуляторних вимог для зниження транзакційних витрат компаній на здійснення експортної діяльності, розбудову механізмів інформачійної, правової та методичної підтримки експортерів, активізацію фрінансової підтримки експортної діяльності. Рекомендації щодо розвитку експортного потенціалу малих $i$ середніх підприємств в Україні можуть бути використані у діяльності центральних органів державної влади, при розробиі національних та галузевих програм розвитку.

Ключові слова: експортний потенціал, малі та середні підприємства, зовнішні ринки, управління зовнішньоекономічною діяльністю.

The article deals with the current state of export activity of small and medium-sized enterprises in Ukraine. The main losses of export potential suffered by Ukrainian economy because of external aggression are determined. The main indicators characterizing the level of export activity of small and medium-sized enterprises are given. The factors limiting the ability of small and medium-sized enterprises to participate in foreign trade and their greater vulnerability to the impact of foreign trade barriers are identified. The factors, that limit the opportunities for small and medium-sized enterprises to participate in foreign trade are as follows: complicated requirements for obtaining regulatory conditions for export operations, a lack of high standards of customs procedures, limited access to information on the situation on foreign markets, low effectiveness of the system for facilitating contacts with potential foreign partners, under-qualified management of small and medium companies, a lack of exhaustively regulated mechanisms of application 
procedures and regulatory requirements in carrying out trade transactions, poor availability of export credit, lack of effectiveness of government programs to support exports, language and cultural barriers. Based on the defined specifics and manifestations of obstacles to the export activities of small and medium-sized enterprises, several public policy measures for the gradual increase of the export potential of small and medium-sized enterprises and strengthening the country's positions in foreign markets are proposed. These measures should be aimed at simplifying the procedures and regulatory requirements that provide the reduction of transaction costs for companies export activities, developing mechanisms for information, legal and methodological support for exporters, enhancing financial support for export activities. Recommendations on the development of export potential of small and medium enterprises in Ukraine can be used by central government bodies, in elaboration of national and sectoral development programs.

Keywords: export potential, small and medium enterprises, foreign markets, foreign economic activity management

Вступ. В умовах воєнного конфлікту на сході України, значного руйнування та пошкодження промислових об'єктів та інфраструктури, найбільших втрат експортного потенціалу економіка України зазнала в галузях, які експортували енергоємну, сировинну і низькотехнологічну продукцію. Так, за даними Держстату, за три роки - з 2014 по 2016 - експорт продукції хімічної та пов’язаних 3 нею галузей промисловості зменшився на 61,1 \%, мінеральної продукції - на 62 \%, дорогоцінних металів та виробів 3 них - на 52,4 \%. На ці галузі приходилося $62 \%$ загального скорочення експорту товарів у цей період. Це галузі, які значною мірою формують експортні можливості країни i представлені переважно великими підприємствами. Крім того, зафіксовано також значне скорочення експорту продукції машинобудування - на 58,2 \%. У цій галузі частка великих підприємств становить понад 50 \%, проте важливу роль має також і середній бізнес.

Зростання експорту у 2017 р. дещо пом'якшило негативний вплив попередніх років. Проте проблема пошуку нових ринків i можливостей на зовнішніх ринках залишається нагальним завданням. Невідновна втрата значної частини експортного потенціалу країни через військові дії на Донбасі унеможливлює відтворення традиційної експортної спеціалізації. Необхідним $\epsilon$ пошук нових ніш і напрямів активізації експорту вітчизняних виробників на зовнішньому ринку. Це вимагає впровадження інструментів підтримки диверсифікації експортних можливостей підприємств, усунення бар'єрів у зовнішній торгівлі для виробників, які незначною мірою представлені на зовнішніх ринках або тільки започатковують експортну діяльність. Це значною мірою стосується малих і середніх підприємств (МСП).

Низка питань, що стосуються зовнішньоекономічного потенціалу МСП, знаходить відображення у працях Я. Жаліло [1], І. Бураковського, О. Крініцина, I. Сологуб [2], загальним проблемам виявлення і подолання бар'єрів для МСП на зовнішніх ринках присвячені дослідження міжнародних організацій, зокрема OECP [3]. Постійна актуалізація загроз для розвитку експортного потенціалу МСП вимагає опрацювання шляхів його посилення на підгрунті виявлення та систематизації перешкод, які обмежують можливості МСП на зовнішніх ринках,

Постановка завдання. Метою статті $\epsilon$ дослідження особливостей експортної діяльності МСП в Україні. Досягнення цієї мети потребує вирішення 
кількох завдань: визначити параметричні характеристики експортної діяльності МСП; виявити основні чинники, що створюють перешкоди для участі МСП у зовнішній торгівлі.

Методологія. Для досягнення мети дослідження використано методи теоретичного дослідження, a саме: структурно-функціональний, метод порівняння, логічний аналіз, метод узагальнення.

Результати дослідження. Національна статистика України не передбачає здійснення системних спостережень щодо зовнішньоекономічної діяльності МСП. Окрему інформацію про це можна отримати з обстежень підприємств, які проводить Світовий банк [4]. Ці дані показують досить низький рівень експортної діяльності сектору МСП в Україні. Серед МСП частка експортерів $\epsilon$ значно нижчою порівняно 3 великими підприємствами. Якщо майже половина (47,5 \%) великих підприємств здійснювали експортну діяльність, то лише 11,7 \% малих і 19,9 \% середніх підприємств були присутні на зовнішньому ринку. Як наслідок, експортна орієнтація МСП є значно нижчою, ніж великого бізнесу. Великі підприємства експортували 18,1 \% реалізованої продукції. Для малих підприємств цей показник був у понад 4 рази меншим (4,1\%), для середніх підприємств - більш ніж удвічі $(8,3 \%)$.

Формування експортного потенціалу МСП вимагає розуміння сукупності чинників i умов, які визначають їх мотивацію брати участь у зовнішньоекономічній діяльності та можливості забезпечувати їі тривалість на певну перспективу. 3 низки причин МСП більш уразливі до впливу торговельних бар’єрів, ніж великі компанії. Навіть за сприятливої економічної ситуації МСП стикаються із значно вищими порівняно 3 великими підприємствами ризиками ведення зовнішньоекономічної діяльності [1]. Великі компанії володіють ресурсами, що дозволяють їм пом'якшувати ризики здійснення експортної діяльності у спосіб: диверсифікації експортних операцій; формування власних зовнішньоторговельних чи міжнародних відділів, які здійснюють постійний моніторинг умов такої діяльності, оцінку ризиків i способів їх мінімізації; досягнення економії за рахунок масштабів експортних операцій; лобіювання сприятливих законів i регуляцій у сфері зовнішньоекономічної діяльності. МСП, як правило, мають обмежені ресурси $\mathrm{i}$ значно вищий рівень чутливості до ризиків [2, с. 73].

\section{с такі:}

Чинниками обмеження можливостей участі МСП у зовнішній торгівлі

1. Наявність необтрунтовано ускладнених вимог щцоо отримання регуляторних умов при здійсненні експортних операцій та надмірних витрат часу $\boldsymbol{i}$ коштів на проходження митних процедур. Проблемою залишаються затримки 3 митним оформленням, які підвищують витрати МСП на здійснення зовнішньоторговельних угод, ускладнюють для них можливості участі у глобальних ланцюгах поставок.

За результатами дослідження Світового банку, майже $13 \%$ середніх підприємств визначили митні правила і процедури регулювання зовнішньої торгівлі однією 3 найважливіших перешкод для їх діяльності. Лише для 5,3\% великих підприємств ці чинники були значимими. Відповідна оцінка для малих підприємств становить 6,7 \%. Оскільки значно менша частка малих підприємств 
є експортерами, вони у своїй діяльності менше стикаються з роботою митниці, необхідністю виконання регуляторних вимог щодо зовнішньоекономічної діяльності і т. ін.

Значний розрив зберігається у показниках витрат на обробку зовнішньоторговельних вантажів. Українські підприємства несуть значно більші витрати часу i коштів на проходження митного контролю і оформлення документів при експорті товарів. Час на оформлення документів для українського експортера становить 96 год., тоді як компанії в країнах $\mathrm{CC}$ витрачають на відповідні процедури 1-3 год., у Туреччині - 2 год., Білорусі - 4 год., Китаї - 21 год., Індії - 38 год., Росії - 25 год. [5]. Відповідно у більшості цих країн нижчими $є$ й витрати на оформлення документів.

За оцінками Звіту про залучення у міжнародну торгівлю [6], найслабкіші позиції Україна має за показниками, які характеризують ефективність i прозорість митних процедур. За показником митних послуг Україна займала 110 позицію серед 136 досліджуваних країн, ефективністю процесу митного оформлення - 104, витрат часу на оформлення документів при експорті товарів 105, вартісних витрат на оформлення документів при експорті товарів - 124 .

\section{2. Обмежений доступ до інформації про ситуацію на зовнішніх} ринках. Це є одним з основних стримуючих бар'єрів для експорту, оскільки ускладнює пошук надійних партнерів і збільшує ризики експортної діяльності МСП. За нестачі компетентності і фінансових ресурсів, МСП часто не в змозі визначати і скористатися новими можливостями на зовнішніх ринках. Навіть у випадку, коли вони визначили можливий новий ринок, МСП часто відчувають реальні труднощі щодо доступу до даних, на основі яких можна оцінити очікуваний прибуток і ризики ведення бізнесу на цьому ринку. Таким чином, виявлення і доступ до відповідної інформації з приватних і державних джерел залишається головним завданням для МСП, які прагнуть вийти на міжнародні ринки. Згідно Звіту про залучення у міжнародну торгівлю [6], проблеми 3 визначенням потенційного ринку і покупців $\epsilon$ найвагомішим чинником, що впливає на експорт в Україні.

3. Низька результативність системи сприяння щодо налагодження контактів з потенційними зарубіжними партнерами. Труднощі у пошуку партнера на зовнішньому ринку $\epsilon$ однією 3 основних перешкод для започаткування експортної діяльності МСП. Підприємствам, які вперше здійснюють експортні операції, бракує знань щодо способів виходу на міжнародні ринки. Додатковим стримуючим чинником стають труднощі отримання доступу до відповідної інфраструктури розподілу товарів (торговельних мереж, торговельних агентів тощо).

В Україні значна частина ініціатив органів влади щодо розширення доступу українських компаній до інформації щодо умов і регулювання зовнішньоторговельної діяльності, забезпечення їх інформацією щодо відповідних тарифних і нетарифних обмежень, зміни регулювання на ринках інших країн має несистемний i негрунтовний характер. Міністерство економічного розвитку i торгівлі України управляє Інтернет-порталом «Державна підтримка українського експорту» (http://www.ukrexport.gov.ua), який надає певну інформацію щодо стану економіки i ринків, особливостей 
законодавства України та країн-партнерів, містить бази даних експортерів, комерційних пропозицій, торгів і тендерів, міжнародних бізнес-заходів тощо. Власне портал насичений інформацією, що стосується різних аспектів здійснення експортної діяльності. Втім практична значимість такого Інтернетресурсу з точки зору досягнення поставлених завдань $є$ надзвичайно низькою. Основні вади полягають у такому: не здійснюється постійне оновлення інформації; окремі блоки порталу заповнені нерівномірно, наведена в них інформація є фрагментарною (наприклад, законодавство країни перебування); низький рівень структурованості поданої інформації; відсутність систематизованого цільового пошуку; переповнення непотрібною інформацією, яка має не цільовий, а радше ілюстративний характер.

До позитивних кроків щодо розвитку системи сприяння українським підприємствам у частині надання консультативної, інформаційної, технічної та організаційної підтримки експортної діяльності суб'єктів МСП слід віднести:

- плани Міністерства економічного розвитку і торгівлі України щодо створення центрів підтримки експорту, створення відповідних центрів у регіональних торгово-промислових палатах;

- започаткування Представництвом України при СС роботи веб-сервісу «Центр підтримки експортерів»;

- утворення Ради експортерів та інвесторів як постійно діючого консультативного органу при Міністерстві закордонних справ України, на який покладено завдання сприяти українським експортерам у зміцненні їхніх позицій на традиційних ринках, у виході на нові ринки збуту, їх участі у тендерах, реалізації інфраструктурних та інвестиційних проектів за кордоном, залученню фінансових ресурсів у виробництво в Україні конкурентної та експортноорієнтованої продукції, реалізації високотехнологічної продукції за кордоном і впровадженні зарубіжних інноваційних технологій, залученню іноземних інвестицій в Україну, просуванню економічних інтересів України за кордоном на двосторонньому і багатосторонньому рівнях;

- утворення Офісу з просування експорту як консультативно-дорадчого органу Міністерства економічного розвитку i торгівлі України, який було створено в якості “єдиного вікна" допомоги українським експортерам в отриманні доступу до зовнішніх ринків.

Значна частина цих ініціатив почали реалізуватися 32015 p. Ïх ефективність визначатиметься спроможністю відповідних інституцій забезпечити достатні фінансові, людські ресурси для їх реалізації, сформувати ефективні механізми взаємодії між різними інституціями, що їх реалізують.

4. Недостатній кваліфікаційний рівень менеджменту компаній щцод управління зовнішньоекономічною діяльністю. Труднощі, обумовлені обмеженими знаннями 3 управління зовнішньоекономічною діяльністю, у поєднанні з сприйняттями ними ризиків такої діяльності стають вагомими стримуючими чинниками для участі МСП в міжнародній торгівлі, передусім у випадку оцінки можливостей для започаткування експортних операцій. Крім того, така діяльність передбачає застосування методів стратегічного управління діяльністю компаній. Проте, у своїй повсякденній діяльності менеджмент МСП 
значною мірою сконцентрований на оперативному управлінні компанією, забезпечення їі життєздатності на найближчу перспективу.

\section{5. Низькі можсливості залучати кваліфікований персонал для} здійснення зовнішньоекономічної діяльності. Процес виходу на зовнішні ринки є досить складним і витратним для будь-якого підприємства. Великі підприємства створюють підрозділи для цілей вивчення ринків, щоденного управління зовнішньоторговельними процесами, оцінки ризиків i пошуку шляхів їх мінімізації. Це досить часто не $є$ можливим у випадку МСП. Для багатьох МСП обмежене знання іноземних ринків діє як значний бар'єр для збільшення їх експорту. Менеджмент МСП має недостатній досвід у вирішенні технічних, юридичних, маркетингових питань у сфері зовнішньоекономічної діяльності, управління ланцюгами поставок тощо. МСП часто не можуть дозволити собі тримати штат фахівців або залучати зовнішніх експертів для започаткування i управління своїми зовнішньоекономічними операціями. У більшості випадків їх невеликий розмір і ресурси не дозволяють наймати персонал, необхідний для виявлення експортних можливостей, встановлення відносин з іноземними покупцями, постійного моніторингу і аналізу вимог щодо ввезення товарів до країн-імпортерів (наприклад, маркування, безпеки споживачів, санітарних i фітосанітарних вимог), змін законодавства, регуляторних вимог вітчизняних органів і на відповідному зовнішньому ринку. Вартість отримання такої інформації є непомірно високою для МСП.

6. Відсутність вичерпно регламентованих механізмів застосування процедур $і$ регуляторних вимог при здійсненні зовнішньоторговельних операціü. У багатьох випадках МСП стикаються із значно вищими ризиками при здійсненні експортних операцій порівняно 3 великими підприємствами внаслідок вищого відносного рівня витрат на виконання вимог митних органів у випадку низького рівня передбачуваності відповідних правил і процедур в умовах їх частих змін і коригувань, застосування різноманітних підходів до визначення митної вартості товарів, вадами механізмів оскарження рішень митних органів.

Значні ризики для МСП виникають в частині дотримання законодавства щодо виконання встановлених термінів повернення виручки від здійснених експортних операцій. Вони виникають внаслідок обмеженої тривалості та нижчого рівня стійкості взаємозв'язків з іноземними контрагентами, значно нижчої спроможності врегульовувати питання щодо порушення ними контрактних зобов'язань тощо. Зокрема, на підприємства-експортери накладаються штрафні санкції за порушення 90-денного терміну повернення валютної виручки. При цьому українське законодавство не передбачає жодних офіційних процедур повідомлення компаній про застосування спеціальних санкцій. Як правило, компанії дізнаються про призначені санкції тільки після того, як вони вже застосовані, і у них залишається єдиний спосіб зупинити дію санкцій, подавши позов до суду [7]. Тобто у випаду недобросовісних дій іноземного контрагента додаткові транзакційні витрати на здійснення експортної діяльності нестиме український експортер - чи на здійснення судового урегулювання цієї проблеми, чи на сплату відповідних штрафів. 


\section{7. Недоступність довгострокового і відносно дещевого експортного}

фінансування. Компанії, які прагнуть вийти на нові ринки, стикаються 3 проблемами нестачі оборотного капіталу для фінансування експорту. Це не лише призводить до зростання витрат на ведення експортної діяльності, але й може поставити під загрозу всю виробничу діяльність компанії. Ця проблема має два аспекти: доступність торговельного фінансування для МСП і доступ до достатнього обсягу оборотного капіталу для здійснення підприємствами економічної діяльності. Торговельне фінансування дозволяє мінімізувати ризики, притаманні торговельним угодам, і гарантує, що експортери отримають оплату за відвантажені товари. Натомість, обсяг оборотного капіталу, який можуть залучити підприємства, має важливе значення для здійснення їхніх щоденних операцій i розширення економічної діяльності, в тому числі експортної.

Обмеження у доступі до фінансових ресурсів є більш вагомими для компаній, які знаходяться на початковій стадії розвитку експортної діяльності, зокрема в частині доступності кредитів для розширення оборотного капіталу $\mathrm{i}$ довгострокових кредитів, а також їх вартості. За даними Звіту про залучення у міжнародну торгівлю доступ до торговельного фінансування $\epsilon$ третьою за значимістю перешкодою для експорту в Україні [6].

\section{8. Низький рівень конкурентоспроможності МСП. Недостатня} конкурентоспроможність значної частини МСП є суттєвою перешкодою для виходу на зовнішні ринки. Причинами цього $є$ глибока нестача інвестицій для технологічної модернізації виробництва і дефіцит мотивації до впровадження інновацій. У промисловості України у 2014-2016 рр. технологічні інновації впроваджували лише 3,8 \% малих і 7,3 \% середніх підприємств, тоді як для великих підприємств цей показник сягав 11,5 \% [8]. Крім того, невідповідність технологій виробництва і навичок, технічні вимоги і стандарти за кордоном i труднощі 3 виконанням вимог покупців визнавалися українськими підприємствами одними 3 вагомих чинників, що стримують розвиток їх експортної діяльності [6].

9. Недостатня результативність держсавних програм підтримки eксnорту. Низький рівень інформованості МСП щодо наявних програм державної підтримки і сприяння виходу на зовнішні ринки, умов і можливостей участі в таких програмах $є$ вагомим стримуючим чинником для розвитку експортної діяльності. Водночас незначний ресурс, який спрямовується на такі цілі, не дозволяє забезпечити суттєві зрушення у розкритті експортного потенціалу вітчизняних компаній.

10. Наявність мовних і культурних бар'єрів. Мовний бар'єр ускладнює пошук необхідної інформації, а також практичні ділові контакти. Такі бар'єри можуть ускладнити, особливо для малих підприємств, пошук іноземних клієнтів і ринків збуту для своєї продукції.

Врахування окресленої специфіки та проявів перешкод для експортної діяльності МСП в процесі вироблення і реалізації зовнішньоторговельної політики в Україні дозволить створити умови для поступового нарощування експортного потенціалу МСП і посилення позицій країни на зовнішніх ринках. Відповідні заходи державної політики мають передбачати: 
1) спрощуення процедур $i$ регуляторних вимог для зниження витрат компаній на здійснення експортної діяльності, виконання митних процедур: впровадження заходів дерегуляції процедур митного оформлення експорту; зменшення кількості документів, необхідних для здійснення митного оформлення експорту; прискорення впровадження дієвої системи електронного документообігу i планомірне впровадження безпаперових технологій в усіх сферах діяльності митної служби; розробка механізму прискорення митних процедур для «надійних» експортерів;

2) розбудову механізмів інформаційної, правової та методичної підтримки експортерів: запровадження регулярного збору статистичної інформації щодо зовнішньоторговельної діяльності МСП; розбудова системи оперативного інформування вітчизняного бізнесу про актуальні проблеми зовнішньої торгівлі, зміни торговельної політики України та основних торговельних партнерів у спосіб проведення навчальних та інформаційних семінарів і тренінгів для представників бізнес-асоціацій, МСП; створення під керівництвом Міністерства економічного розвитку і торгівлі у взаємодії з МЗС, іншими міністерствами і відомствами, Торгово-промисловою палатою України, об'єднаннями підприємств навчальних програм, проведення спеціальних семінарів i тренінгів для менеджменту, представників МСП щодо умов здійснення зовнішньоекономічної діяльності, сучасних методів і механізмів управління експортними операціями; створення мережі регіональних центрів сприяння експорту, орієнтованих на надання інформаційних, консультаційних i маркетингових послуг для вітчизняних виробників в частині вимог щодо якості продукції, іiі сертифікації, послуг з пошуку потенційних партнерів, організації експортних операцій; створення комплексної інформаційної платформи в галузі зовнішньоторговельної діяльності;

3) активізації фінансової підтримки експортної діяльності: упровадження механізмів експортного кредитування i страхування шляхом завершення створення спеціалізованого експортно-кредитного агентства; впровадження програм довгострокового експортного кредитування МСП.

Висновки. Експортний чинник в Україні традиційно виконував роль рушійної сили відновлення економіки країни після втрат у кризові періоди. Внаслідок зовнішньої агресії на Донбасі Україна зазнала істотних втрат промислових потужностей, які в попередні періоди були вагомим чинником пожвавлення виробництва в екпортоорієнтованих галузях промисловості. Значний негативний вплив на показники експортної діяльності мав також чинник втрати низки зовнішніх ринків. Відтак пошук можливостей для освоєння нових ніш на зовнішніх ринках $є$ надзвичайно нагальним для країни. Саме розбудова експортного потенціалу МСП може стати чинником компенсації втрат України на традиційних зовнішніх ринках.

Наукова новизна результатів дослідження полягає у систематизації головних чинників, які створюють перешкоди для розвитку експортного потенціалу МСП, і визначення на підгрунті цього рекомендацій для державної політики, зорієнтованих на поступове посилення позицій країни на зовнішніх ринках. Практичне значення проведеного дослідження полягає у тому, що рекомендації щодо розвитку експортного потенціалу МСП в Україні можуть 
бути використані у діяльності центральних органів державної влади, при розробці національних та галузевих програм розвитку. Подальші дослідження експортних можливостей МСП мають бути спрямовані на визначення їх галузевих особливостей та визначення фінансових механізмів підтримки виходу МСП на зовнішні ринки.

\section{Лiтература:}

1. Zhalilo Y. A. SMEs, Trade and Economic Development in Ukraine. Geneva: International Trade Centre, 2015. $47 \mathrm{p}$.

2. Політика сприяння експорту МСП в Україні / І. Бураковський, О. Крініцин, І. Сологуб. URL: http://www.ier.com.ua/files//publications/Policy_papers/IER/2016/LEV/Krinitsyn_SME_Export_ Promotion.pdf (дата звернення: 07.03.2018)

3. Removing Barriers to SME Access to International Markets. Paris: OECD, 2008. 214 p.

4. Ukraine (2013) / World Bank Enterprise Surveys. URL: http://www.enterprisesurveys.org/data/exploreeconomies/2013/ukraine (дата звернення: 07.03.2018)

5. Doing Business 2018: Reforming to Create Jobs. Washington, DC: World Bank, 2018. 303 p.

6. The Global Enabling Trade Report 2016. Geneva: World Economic Forum, 2016. 329 p.

7. Системний звіт «Проблемні питання регулювання зовнішньоекономічної діяльності в Україні» (Жовтень 2015) / Рада бізнес-омбудсмена URL: https://boi.org.ua/media/uploads/q3report/sysrep_tax_ukr_pdf.pdf (дата звернення: 09.02.2018)

8. Обстеження інноваційної діяльності в економіці України за період 2014-2016 років (за міжнародною методологією) / Держстат України. URL: http://www.ukrstat.gov.ua/druk/publicat/kat_u/2017/dop/11/dop_inn_2016.zip (дата звернення: 09.02.2018) 